\title{
PROPUESTA DE UN MODELO HOLÍSTICO MULTIMODAL PARA UNA LECTURA CRÍTICA DEL RACISMO DISCURSIVO EN LA PRENSA ESCRITA
}

\author{
PROPOSAL OF AN HOLISTIC MULTIMODAL APPROACH \\ FOR CRITICAL READING OF THE DISCURSIVE RACISM ON WRITTEN PRESS
}

\author{
Julio SÁEZ GALLARDO \\ Investigador independiente \\ juliosaez2005@yahoo.es
}

\begin{abstract}
Resumen: El objetivo de este trabajo es proponer un Modelo holístico multimodal para una lectura crítica del racismo en la prensa escrita. Para ello, desde el Análisis Crítico del Discurso Multimodal (ACDM), usamos como estrategia teórico-metodológica integradora las aportaciones de Teresa Velázquez (2011) y su modelo semióticodiscursivo; el modelo sociocognitivo de van Dijk (1990, 1997a, 2003a, 2003b); el modelo de la semiótica visual de Kress y van Leeuwen (1996) y el modelo intersemiótico de Nikolajeva y Scott (2001). Se validan las matrices de análisis aplicándolas al llamado conflicto mapuche en Chile para extraer resultados y conclusiones valederas en torno a la representación periodística de las minorías étnicas.
\end{abstract}

Palabras clave: ACDM. Prensa escrita. Racismo discursivo. Modelo holístico multimodal.

\begin{abstract}
This work aims to propose a holistic multimodal approach for making critical reading about racism in the written press. In order to achieve this, and taking account the Multimodal Critical Discourse Analysis, we use as theoretical and methodological integrative strategies the contributions of Teresa Velázquez and her discursive-semiotic approach (2011), van Dijk's sociocognitive approach (1990, 1997a, 2003a, 2003b), Kress and van Leeuwen's visual semiotics approach (1996), and Nikolakeva and Scott's intersemiotic approach (2001). The analysis matrices are validated using the so-called mapuche conflict in Chile in order to be able to draw conclusive results and conclusions about media representations of ethnic minorities.
\end{abstract}

Keywords: MCDA. Written press. Discursive racism. Holistic multimodal approach. 


\section{INTRODUCCIÓN}

Esta contribución intenta aportar, desde el Marco del Análisis Crítico del Discurso (ACD), un cuerpo teórico-metodológico que logre ser una herramienta hermenéutica para una comprensión más global e integral acerca de cómo los medios escritos construyen la noticia y las representaciones sociales sobre las minorías étnicas, tanto aborígenes como migrantes, en sociedades cada más globalizadas como las nuestras. Sociedades en donde la construcción de sentidos se logra cada vez más a través de la articulación de una gama de recursos y sistemas semióticos, dando paso a la multimodalidad discursiva, es decir, la concurrencia de numerosos sistemas sígnicos para la re-producción de sentidos. Por lo cual, se asume en este trabajo una perspectiva propositiva desde el Análisis Crítico del Discurso Multimodal (ACDM).

Diversas investigaciones (Alonso et al., 2010; Checa y Olmos, 2008; Lario, 2000; Markovitz, 2011; Martínez, 2006, 2008, 2010) dan cuenta de que los medios de comunicación ofrecen una interpretación ideológico-racista cuando se refieren a las minorías étnicas, al asociarlas a diversas formas de desviación (delitos, violencia y diferencias culturales) y hacen que se perciban como problemáticas y que no se avienen con el estilo de vida y valores de la sociedad mayoritaria.

\subsection{Objetivo}

En consideración a lo señalado, en este trabajo nos interesa como objetivo central proponer un Modelo holístico multimodal para el análisis del racismo discursivo proveniente de los medios de comunicación escritos. Para ello, se elabora una base teórico-metodológica que sustente la construcción de un modelo integral que abarque todos los componentes semióticos de un texto noticioso que interactúan para la creación de sentido cuando de la construcción sociosemiótica de la alteridad étnica se trata.

\subsection{Metodología}

Para lograr nuestro propósito, optamos por trabajar con cuatro aportaciones teóricometodológicas desde una lógica modélica coherente, integradora y pertinente. En primer lugar, revisamos el modelo de análisis socio-semiótico propuesto por Teresa Velázquez (1982, 1992 y 2011). En segundo lugar, nos proveemos de unas herramientas analíticas que derivan del modelo sociocognitivo de Teun van Dijk (1990, 1997, 2003a, 2003b). Para ello, usamos como categorías de análisis de aristas del cuadrado ideológico que aporta van Dijk (1999). Posteriormente, se deconstruye la ideología del racismo desde una óptica multimodal para revisar las elecciones periodísticas en lo relativo a la construcción de las fotografías que acompañan el texto noticioso. En este aspecto, usamos las posibilidades heurísticas que nos ofrece el modelo de la semiótica visual de Kress y van Leeuwen (1996). A continuación, describimos el modelo propuesto por Nikolajeva y 
Scott (2001) quienes nos proveen un estudio de la interacción del texto escrito y la imagen desde una mirada intersemiótica. Finalmente, y para validar las categorías teóricometodológicas propuestas contenidas en las matrices de análisis, damos a conocer los resultados obtenidos al aplicar este Modelo holístico multimodal a un corpus de noticias acerca del denominado conflicto mapuche en Chile. Para lo cual se analiza el tratamiento que los diarios La Cuarta y El Mercurio le otorgan a la huelga de hambre de los prisioneros mapuches en los años 2010 y 2020. El referido análisis se hace con un criterio contrastivo, vale decir, se comparan las noticias sobre la protesta étnica para determinar el tratamiento que le otorgan los medios estudiados al gobierno y poderes del Estado y a los prisioneros aborígenes para, de este modo, determinar si existe una construcción periodística diferenciada entre el endrogrupo y el exogrupo.

\subsection{El conflicto mapuche y la protesta indígena: breve contexto}

El llamado conflicto mapuche se ha desarrollado en Chile durante la década de los noventa del siglo pasado y tiene una característica que lo diferencia radicalmente de otros periodos de la historia, a saber: la fuerza con que reivindica, por parte de esta etnia, su particularidad sociocultural respecto al resto de la sociedad chilena. Así, junto a las históricas exigencias económicas (tierras agrícolas, subsidios, capacitación, becas de estudio, etc.) se han desarrollado exigencias de tipo político y cultural. En este sentido, se empieza a plantear el tema de la autonomía política y territorial del pueblo mapuche y la exigencia de ser reconocidos como un Otro distinto del resto de la sociedad chilena, con derechos que surgen de su particularidad, tal y como indica Bengoa (1999).

Para Bengoa (1999) el origen del conflicto entre la comunidad mapuche y el estado de Chile se encuentra en la política de colonización y reparto de tierras que el Estado aplicó a fines del siglo 19, posterior a la ocupación militar de la zona. De acuerdo al autor, los mapuches obligados a vivir en reservaciones se empobrecieron y fueron víctimas de la nostalgia y el desarraigo: "Allí se constituye, a mí modo de ver, la cultura mapuche moderna. Combinación de nostalgia, resentimientos y afirmación de su propio futuro e identidad. Se originan sin duda los odios primordiales" (Bengoa, 1999:16).

Por su parte Mella (2008) desde una perspectiva crítica analiza el rol del estado chileno frente al conflicto mapuche y pone de relieve la sistemática criminalización de los mapuches - en particular - y de todos los movimientos sociales en América Latina - en general - como estrategia de control social en defensa del paradigma neoliberal en resguardo de los capitales de los inversores locales y las empresas transnacionales. Plantea que en la actualidad el estado chileno utiliza el proceso penal como método de control social. Mella (2007) afirma que el mismo marco legal le entrega al Estado chileno facultades exageradas que le permite aumentar en varios grados las condenas e incluso suspender garantías procesales que aseguren un debido procesamiento para los inculpados. Precisamente, las huelgas de hambre de prisioneros mapuches no tienen otro objetivo que el de protestar frente al Estado chileno por la aplicación de leyes 
excepcionales como la ley antiterrorista a los presos mapuches que han sido encarcelados por intentar recuperar sus tierras ancestrales de las manos de las empresas forestales transnacionales.

\section{FUNDAMENTACIÓN TEÓRICA}

\subsection{La gramática de lo visual para el análisis de la creación de significados}

Dentro de esta vertiente teórica es posible que el esfuerzo más profundo por estudiar las regularidades y estructura de lo visual esté dado por la obra de Kress y van Leeuwen (1996) quienes incorporan de manera sistemática las categorías analíticas de la Gramática Sistémica Funcional de Halliday (2004) al estudio de las semióticas no verbales y las relaciones entre los distintos modos. La obra de estos autores propone métodos para analizar tanto la iconografía, el equivalente de una lexis, como de una teoría del diseño análoga a la sintaxis. Basada en una concepción social de la comunicación, intenta explicar las convenciones variables que regulan el uso de la imagen para construcción del significado.

La propuesta que desarrollan Kress y van Leeuwen en Reading Images (1996:13-14) permite investigar y develar qué tipos de significados de lo social se comunican en el componente verbal y visual de los mensajes. Para nuestro trabajo es de gran productividad, por cuanto se hace posible analizar de qué forma los diversos mecanismos semióticos se articulan para transmitir prejuicios, valores e ideologías respecto del endogrupo y exogrupo. La mencionada metodología será tomada aquí como herramienta analítica para deconstruir un corpus multimodal.

Uno de los problemas a que se ven enfrentados los teóricos del discurso multimodal dice relación a la complejidad semiótica surgida por las relaciones entre los diversos recursos semióticos utilizados para crear significado. Por ello, han optado por considerar la dimensión intersemiótica de la comunicación visual como una herramienta analítica útil para investigar lo que ocurre cuando los recursos semióticos son co-utilizados para crear significado, mediante la orquestación de los diversos recursos (Jewitt y Kress, 2003). El referido enfoque teórico nos provee una interesante posibilidad para el análisis del corpus multimodal en donde palabras e imágenes se articulan para producir semiosis de la alteridad étinica.

Dentro de esta línea de investigación rescatamos para nuestros propósitos el concepto de complementariedad intersemiótica acuñado por Royce $(1998,2007)$ para analizar cómo los modos verbal y visual se complementan semánticamente para producir un solo fenómeno textual. La noción de complementariedad intersemiótica entre lengua e imagen visual implica que ambos recursos realizan un trabajo semiótico conjunto para producir un texto multimodal coherente. 


\subsection{El análisis multimodal del discurso y su aplicación a los estudios del racismo discursivo}

Existe un creciente interés de las ciencias sociales por abordar el fenómeno del racismo, dada la centralidad y visibilidad que han adquirido social y mediáticamente problemas socio-políticos que se vinculan con esta temática en las sociedades contemporáneas, a saber: por un lado, los procesos migratorios desde países subdesarrollados o periféricos a naciones más estables económica y políticamente, como es el caso de lo que ocurre en Europa y, por otro, los movimientos indígenas reivindicativos de derechos ancestrales, específicamente situados en América Latina.

Es esta doble vertiente del racismo tomada como contexto que nos motiva a indagar en los distintos esfuerzos investigativos realizados por académicos del AD interesados por reflexionar en las características de la construcción discursivo-ideológica del Otro. No sin antes precisar en este punto, la noción de racismo que guía este trabajo. Para lo cual, compartimos la aproximación conceptual propuesta por van Dijk, quien señala que

[...] el racismo es principalmente un sistema de dominación y de desigualdad social [...] La dominación se define como el abuso de poder de un grupo sobre otro, y está representada por dos sistemas interrelacionados de prácticas sociales y sociocognitivas cotidianas, es decir, por varias formas de discriminación, marginación, exclusión o problematización por un lado y por creencias, actitudes e ideologías prejuiciosas y estereotipadas por otro (Dijk, T. van, 2006: 17).

Por otro lado, nos interesa, además, dar cabida en este trabajo a distintos aportes que den cuenta del racismo discursivo desde una óptica multimodal, en el entendido que las sociedades actuales son de naturaleza multimodal (Baldry, 2000; Kress y van Leeuwen, 2001 y Unsworth, 2008).

En este breve estado del arte que emprendemos encontramos aún escasos esfuerzos investigativos que den cuenta del uso de este prisma teórico-metodológico. Algunas de las interesantes investigaciones acerca del racismo discursivo con enfoque multimodal centradas en el tratamiento periodístico que se les otorga a las personas migrantes en España, proviene del aporte de Martínez (2010a, 2010b). A modo de ejemplo citamos dos trabajos de esta investigadora: "Hacia una deconstrucción de la ideología de la inmigración en la prensa gratuita través de las palabras y las imágenes" y "Recursos léxicos y visuales en la representación periodística del inmigrante", artículo escrito en conjunto con Crespo. Son, además, importantes los trabajos multimodales de Lorite (2010), por lo que citamos a modo de ejemplo uno de sus aportes: "Televisión informativa y modelos de dinamización intercultural”.

En Latinoamérica, especialmente en Brasil, un grupo reducido de investigadores han centrado su interés en el racismo multimodal, como es el caso de Pinheiro y Magalhães (2011) con su trabajo denominado "Representações de identidades raciais em capas da revista Raça Brasil: um estudo à luz da gramática do design visual.”; Vicentini y do 
Carmo (2010), con un trabajo titulado "Um estudo da representação sociossemiótica do negro na revista Raça Brasil” o Florêncio de Barros y Pagliuchi da Silveira (2018), con su investigación denominada "A representação do negro no regime escravocrata brasileiro em texto multimodal”, por mencionar algunos trabajos en esta línea particular. En Colombia, Pardo (2012) propone un Estudio Crítico del Discurso Multimodal (ECDM) para analizar los discursos que circulan en You Tube en relación con la pobreza y los problemas del racismo en un artículo denominado "Exploraciones sobre la pobreza y el racismo en Colombia. Un estudio Multimodal”. En Chile, Sáez (2015) aborda con enfoque proveniente de la semiótica multimodal el conflicto mapuche en su tesis doctoral titulada Deconstrucción de la discriminación y el racismo discursivo referente a la cultura mapuche en la prensa chilena de mayor lectura.

\section{PROPUESTA METODOLÓGICA: HACIA UN MODELO HOLÍSTICO MULTIMODAL PARA LA INTERPRETACIÓN DEL RACISMO DISCURSIVO}

\subsection{Posicionamiento epistemológico previo}

En este acápite bosquejamos brevemente las coordenadas epistemológicas que guían esta propuesta metodológica que permite analizar los procesos de construcción de la noticia acerca de la alteridad étnica.

\subsubsection{Análisis crítico del discurso multimodal}

Para desarrollar el proceso deconstructivo de los mensajes periodísticos sobre el Otro étnico, asumimos los principios teórico-metodológicos del Análisis Crítico del Discurso Multimodal (ACDM) con una clara perspectiva holística. En este sentido, por tanto, en este trabajo entendemos dicha perspectiva como una

Posición teórica en la que se desarrollan diferentes procedimientos metodológicos, para analizar discursos que se han configurado a través de diversos modos semióticos y que, por ende, requieren ser interpretados a la luz de diferentes disciplinas que puedan dar cuenta del sentido y del significado de los recursos semióticos que se emplearon. (Rodríguez, D y Velásquez, A. 2011:41).

Se pretende, en consecuencia, reconocer e interpretar los diversos recursos semióticos que se encuentran imbricados e interrelacionados para la configuración periodística de las minorías étnicas, con arreglo a la utilización de diversas perspectivas teóricometodológicas para el abordaje de la ideología racista, según lo proponemos aquí. En tanto, la asunción de un modelo holístico en este trabajo presupone una mirada abarcadora, integradora de todos los elementos semióticos que se encuentran en un texto multimodal, como lo son el lenguaje y las imágenes que acompañan el texto periodístico 
para producir semiosis social en torno a los procesos de representación social de las minorías étnicas.

El Análisis Crítico del Discurso Multimodal (ACDM) se entenderá en esta propuesta inevitablemente subsumido en el Análisis Crítico del Discurso, en razón que el ACD toma partido por un análisis integral, crítico y denunciante de la dominación, el abuso de poder y la desigualdad social y la discriminación.

\subsubsection{Discurso e ideología racista}

Compartimos con Wieviorka (1992) que la ideología del racismo, a través de diversas experiencias históricas, puede presentar varios niveles de intensidad, en algunos casos puede ser débil y limitado y en otras, fuerte. Es por ello que al abordar este fenómeno social debemos reconocer diferentes planos de intensidad, de presencia y de integración de sus formas elementales - prejuicio, discriminación, segregación y violencia, como indica Wieviorka (1992) - No obstante, postulamos que — dada cada vez más una conciencia social que percibe negativamente el racismo flagrante y torpe - ha llevado a mutar estas formas explicitas por unas nuevas manifestaciones menos vistosas en el plano del discurso verbal o no verbal. Por ello, es de nuestro interés enfocarnos en las manifestaciones concretas del racismo que pueden albergarse en el discurso como una realidad empírica que es susceptible de encontrase en los textos noticiosos.

Al considerar en este trabajo el discurso como forma de interacción social, el ACD lo considera un mediador por el que se puede reproducir, legitimar y perpetuar el racismo. Tal como lo expresa van Dijk (2005), la discriminación racial, o el nuevo racismo se expresa y se confirma, entre otras formas, a través del texto y habla (conversaciones informales, medios de comunicación, debates, entrevistas, etc.) y su efecto, aunque en un principio no lo parezca, es igual de eficaz que otras formas más explicitas de discriminación.

\subsection{EI modelo holístico multimodal}

En este apartado estamos en condiciones - siempre desde un enfoque deductivopresentar visualmente el Modelo que proponemos y que pretende ser comprehensivo e integrador de diversas corrientes teóricas y autores para los propósitos ya expuestos. 


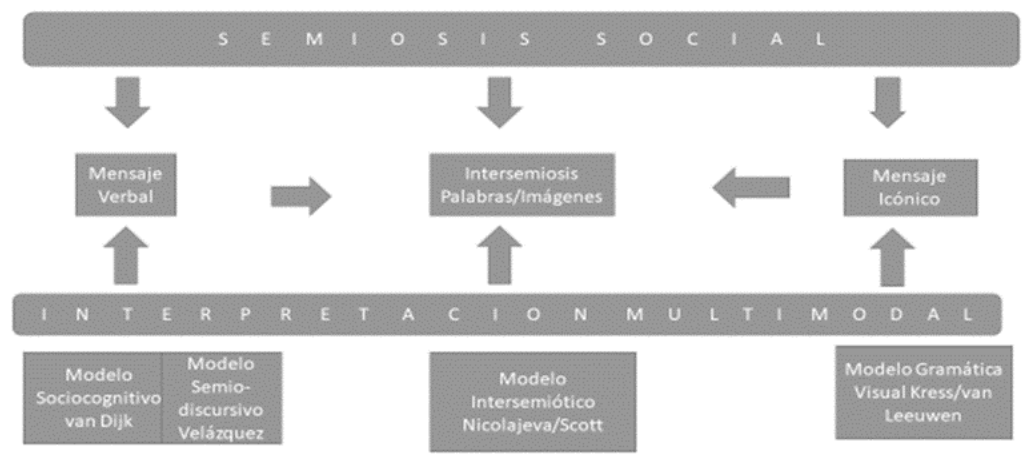

Fuente: Creación del autor.

El paso siguiente será describir someramente las teorías o modelos que generan sinergia para un análisis integral del racismo en la prensa escrita. Lo señalado nos permite definir y determinar las categorías analíticas y técnicas subsumidas en dichos constructos teóricos para, posteriormente, elaborar las matrices de análisis para los fines de una interpretación multimodal de nuestro objeto de estudio.

\subsubsection{Modelo de análisis semiótico-discursivo del texto periodístico de Teresa Velázquez (1982, 1992, 2011)}

Para entender el CÓMO se dice LO QUE se dice seguiremos la propuesta metodológica de Teresa Velázquez (2011) en tanto categorías e instrumento de análisis propuestos. La referida autora desarrolla su Modelo semiótico-discursivo apoyándose en la semiótica estructural de Greimas y la teoría del texto de van Dijk. En virtud de lo dicho, utilizaremos como categorías de análisis dentro de la matriz de trabajo las siguientes: las funciones y modalidades del modelo actancial de Greimas, los niveles textuales como la superestructura, la macroestructura y la acción comunicativa como actos de habla que corresponden a las vertientes de la teoría y análisis del discurso.

Junto con Imbert (1985) creemos que el periódico se constituye en un espacio de figurativización que se articula en varias operaciones: figurativización enunciativa, figurativización actancial y figurativización modal. En razón de este espacio figurativo Velázquez (2011) propone analizar cómo la prensa como sujeto semiótico genera estrategias discursivas en el ámbito de la enunciación, específicamente en la actualización de los actantes del discurso periodístico y cómo las noticias — que tejen un entramado con otras y que pueden concebirse como un relato- son susceptibles de ser analizadas en niveles semántico-narrativos (Greimas).

En este sentido, abordamos a continuación las categorías greimasianas plasmadas en su modelo actancial y las modalidades narrativas implicadas que pasaremos a explicar brevemente a continuación, siempre basados en el trabajo de Velázquez (2011). El modelo actancial se refiere a las funciones narrativas que los personajes del relato 
cumplen en la estructura profunda del mismo y en el recorrido narrativo. El actante es una unidad autónoma dentro del relato y que tiene capacidad de acción. Corresponde al personaje identificado de un relato en el nivel de superficie de la narración. Greimas presenta seis posibles figuras actanciales: destinador/destinatario; narrador/narratario; sujeto/objeto; ayudante/opositor, los cuales se relacionan mediante tres ejes: eje de la comunicación, modalizado por el saber; el eje del deseo, modalizado por el querer y el eje de la participación modalizado por el poder. Estos ejes proporcionan los predicados modales, donde se ubican, tanto el estado de los actantes, como sus acciones, mediante los auxiliares ser, referido al estado y cualidad del actante hacer que dice de sus acciones. Por otra parte, a lo largo del relato, un actante puede cumplir diferentes funciones actanciales. Las funciones actanciales y los predicados modales forman parte del programa narrativo del relato. Los actantes deben cumplir con los contratos modales, sean de estado o de acción que contraen en el relato.

3.2.1.1. La superestructura de la noticia como instrumento analítico para el discurso periodístico

En primer lugar, Velázquez (2011) es tributaria del concepto de superestructura aportado por van Dijk (1983) y la entiende como la organización y clasificación del contenido o macroestructura de la noticia en una serie de categorías jerarquizadas. Así, la superestructura quedaría resuelta como sumario y cuerpo de la noticia. El primero incluiría el titular, entradilla y lead y el segundo contendría los acontecimientos, las consecuencias y reacciones y la interpretación.

\subsubsection{Las macroestructuras de la noticia como nivel de análisis}

Existen ciertos elementos que son típicos de los medios de comunicación como las macroestructuras y que entrañan — como otros elementos del discurso periodístico - una función persuasiva frente al lector para dar eficacia al mensaje, mediante la construcción de representaciones sociales que luego deviene en modelos mentales de la realidad social. Se entiende como macroestructura al contenido o tema global del texto. Se expresa, al ser semántica, por medio de una macroproposición que debe incluir en ella todos los temas que aparecen a lo largo del discurso en sus diferentes segmentaciones temáticas. En el texto periodístico, si está bien escrito, se encontrará en el titular y en el lead o primer párrafo de la noticia; a veces también puede encontrarse en la entradilla.

3.2.1.3. La acción comunicativa como actos de habla asociados al discurso de la discriminación y el racismo en la prensa escrita

En la metodología propuesta se debe tomar el titular de las noticias del corpus y el primer párrafo o lead. Los titulares suelen expresar la macroestructura semántica de la 
noticia; además, dada su prominencia gráfica y textual, suelen favorecer una interpretación preferencial del evento (Dijk, van T., 1997b). El lead suele resumir el acontecimiento más importante y significativo de la noticia (González, 2002), presentando los actores principales.

Si nuestro objetivo es determinar la intencionalidad del discurso de la prensa al referirse a la construcción del Nosotros/los Otros debemos tener en cuenta en el análisis — de acuerdo al modelo propuesto por Velázquez (2011) — los indicadores pragmáticos referidos a los actos de habla que emplea la prensa estudiada en su doble función. Por un lado, se analiza cuál es el acto comunicativo que se realiza en cada uno de los segmentos discursivos de la noticia y, por otro, el macroacto de habla global de toda ella. Para lo cual, nos basamos en la teoría de los actos de habla (Austin (1971); Searle (1980) y Habermas (1987).

Concordamos con van Dijk (1978) que la noticia funciona esencialmente en términos pragmáticos como afirmación. Sin embargo, coincidimos con Velázquez y Fontcuberta (1986) que en muchos casos la noticia no funciona pragmáticamente como afirmación, sino que como indicador de intencionalidad ${ }^{1}$, pues detrás de esta aparente objetividad y verdad periodística de los actos de habla expositivos (afirmar) usados por la prensa se puede apreciar la intencionalidad de construir unas estrategias discursivas que replican el discurso ideológico de la dicotomía ELLOS/NOSOTROS.

\subsubsection{El modelo sociocognitivo de van Dijk (1990, 1997, 2003a, 2003b)}

Para cumplir nuestro objetivo seguimos en este trabajo los aportes de van Dijk y su modelo sociocognitivo (1990, 1997a, 2003a, 2003b) y que ocupamos en esta investigación como matriz analítica por cuanto presenta varias ventajas por sobre otros métodos de análisis de textos, ya que permite no solamente acceder a la información directa o explícita, sino que, nos posibilita ir más allá, poniendo en evidencia valores, opiniones, ideologías, prejuicios, etc., que de otra forma pasarían desapercibidos. Además, sitúa los hechos en un contexto histórico y social, haciendo mucha más profunda la observación y análisis de ellos. Por ende, este trabajo se basa en las relaciones sociocognitivas de la ideología y la forma cómo ésta se manifiesta en el discurso como práctica social.

Van Dijk (1997a), nos propone un marco conceptual adecuado para el estudio del discurso y que podemos resumir en tres conceptos principales, a saber: discurso, cognición y sociedad. El referido autor, sostiene que estos conceptos se encuentran interrelacionados al representar los tres vértices de un triángulo, en el que se relacionan, por un lado, discurso y cognición, así como discurso y sociedad, y así para los otros dos conceptos. Explica que todos los vértices del triángulo son condiciones conceptual y

\footnotetext{
${ }^{1}$ En este trabajo las autoras proponen hablar de Interpretación como categoría superestructural que se presenta como explicita (valoración) e implícita (como intencionalidad) en lugar de la categoría de “comentario", propuesta por van Dijk (1978). Véase, también, Fontcuberta y Velázquez (1987).
} 
empíricamente necesarias para los demás, y fundamentales para la definición de la humanidad en sus órdenes social, cognitivo y discursivo. Su propuesta teórica es interesante y de ella tomamos para entenderla su conceptualización de discurso en la que integra todos los componentes del triángulo. Para van Dijk (1997a) el discurso es

[...] una forma de uso lingüístico y, de forma más general, como un tipo de interacción social, condicionada por la cognición y socialmente contextualizada por los participantes, tomados como miembros sociales en situaciones sociales. El discurso, ya sea oral y escrito, se define, pues, como un evento comunicativo de un tipo especial, estrechamente relacionado con otras actividades comunicativas no verbales (tales como los gestos o el tratamiento de la imagen) y otras prácticas semióticas de significado, de significación y con los usos sociales de códigos simbólicos, como los de la comunicación visual (por ejemplo, los gráficos, la fotografía o el cine) (van Dijk, 1997a: 68).

Esta conceptualización sugiere múltiples relaciones con la cognición y con la sociedad y nos lleva a plantear junto con este autor que el discurso más que tener significados, los usuarios de las lenguas le asignan significados. Asignaciones o interpretaciones que son de naturaleza tanto cognitiva como social. La teoría que hemos esbozado es importante para esta parte del trabajo, ya que van Dijk (1997a) plantea que la cognición se encuentra en la cima del triángulo, que regula y actúa como mediadora entre la sociedad y el discurso. "De hecho, concebimos la cognición como la mediación (interface) entre la sociedad y el discurso" (Dijk, T. van, 1997a: 68). Aportación vital para este trabajo puesto que no podemos concebir una relación entre discurso y sociedad sin las representaciones mentales, interface que explicaría cómo las estructuras sociales condicionan el discurso y viceversa y cuáles son las funciones culturales y sociales del discurso y entender de paso las razones por las cuales los participantes actúan como miembros de un grupo.

En todo discurso ideológico existe un enfrentamiento más o menos explícito entre un grupo social y otro. El Nosotros representa al grupo con el cual el productor del discurso se siente identificado, y con el que comparte formas de comportamiento social y de interpretación de la realidad; los Otros, en contraste, representan un peligro, porque cuestionan lo establecido, tal y como hace notar Arrunátegui (2010). El enfrentamiento entre el Nosotros y los Otros en el discurso se manifiesta a través de la polarización de las características positivas atribuidas al Nosotros y de las características negativas atribuidas al Otro, en términos de van Dijk (2010). Esta polarización de características positivas y negativas constituye, en conjunto, lo que van Dijk (1999) ha denominado el cuadrado ideológico o la estrategia global del discurso ideológico, cuyas aristas corresponden a: 1. Enfatizar lo positivo de Nosotros; 2. Enfatizar lo negativo en los Otros; 3. Desenfatizar los positivo de los Otros; y 4. Desenfatizar lo negativo del Nosotros. En el análisis pasaremos a revisar las estrategias discursivas que reproducen el cuadrado ideológico y consecuencialmente, la frontera simbólica entre el Nosotros y los Otros.

Mediante estos cuatro movimientos, es posible hacer una representación ideológica acerca del énfasis en nuestros aspectos buenos y en sus aspectos malos y, recíprocamente, la negación o atenuación de nuestros aspectos malos y de sus aspectos buenos (van Dijk, 
2005). El uso de las categorías poner y quitar énfasis como parejas opuestas refleja dos aspectos básicos: primero, la estructura polarizada interna de las ideologías que establece el conflicto entre grupos opuestos y sus formas de interacción; y segundo, caracteriza la manera de cómo, en el discurso, se expresan acerca de Nosotros y de los Otros como grupos sociales, los cuales marcan "representaciones de la posición social de los grupos internos y los grupos externos, y su asociación con lo que se define como bueno y malo" (van Dijk, 2005: 61).

\subsubsection{El modelo de la semiótica visual de Kress y van Leeuwen (1996)}

La propuesta teórico-metodológica que desarrollan Kress y van Leeuwen en Reading Images (1996:13-14) permite investigar y develar qué tipos de significados de lo social se comunican en el componente verbal y visual de los mensajes. Para nuestro trabajo es de gran productividad, por cuanto se hace posible analizar de qué forma los diversos mecanismos semióticos se articulan para transmitir prejuicios, valores e ideologías respecto del endogrupo y exogrupo. Para estos autores el análisis de las imágenes se puede abordar tomando en consideración las 3 funciones básicas del lenguaje, conceptos extraídos de la gramática Sistémico-funcional de Halliday (2004). Por ende, los significados sociales de las imágenes serán representacionales, composicionales e interpersonales.

El significado representacional está relacionado con la imagen del mundo que se construye en cada noticia, vale decir, cómo son retratados los participantes y sus acciones y de qué forma se relacionan entre sí. Las estructuras representacionales o ideacionales pueden ser narrativas o conceptuales. Las primeras se dan a través de vectores de movimiento (acción) o bien a través de la mirada (reacción). Se presentan acciones o acontecimientos en desarrollo, procesos de cambio o disposiciones espaciales transitorias. Estas últimas, denominadas "reaction images" (Kress y van Leeuwen, 1996: 56). Por otro lado, las imágenes serán conceptuales si no incluyen vectores de movimientos y representan a los participantes en términos de su esencia más generalizada e intemporal, vale decir, se centran en rasgos como edad, raza, clase social, entre otros.

La función o significado composicional analiza la situación de los elementos representados en cuanto a su valor informativo, saliencia (prominencia) y encuadre (framing) dentro de la imagen. El valor informativo se basa en lo que socialmente está determinado para las distintas zonas de la imagen. Desde esta perspectiva - y considerando los parámetros culturales occidentales - la polarización derecha/izquierda, representa lo conocido y lo nuevo, respectivamente; mientras que la dicotomía arriba/abajo, las dimensiones de lo ideal y de lo real. Además, lo central/marginal ofrece interpretaciones de lo que se considera como importante o periférico culturalmente. En tanto, la prominencia de la imagen se relaciona con la atribución de la importancia que poseen ciertos actores o hechos a través del uso de ciertas características en la imagen, (como por ejemplo el tamaño, uso primer y segundo plano, contrastes, texturas, 
iluminación, etc.), el encuadre contribuye a cómo se entienden los elementos de una imagen en términos de pertenencia o unidad (Kress y van Leeuwen, 1996).

Por último, el significado interpersonal se refiere a las relaciones sociales y emocionales que se generan en la interacción comunicativa, es decir, a la interacción entre los participantes y eventos y el observador de la imagen. Por ello, los elementos que se consideran en las imágenes son el contacto simbólico, la actitud y la distancia social. El contacto simbólico se refiere al contacto visual entre los participantes y entre éstos y el espectador. Estos pueden dirigir su mirada al espectador (demanda) o bien solicitando su compromiso (oferta). En cuanto a la actitud alude al grado de implicación del productor y receptor de la imagen con las entidades representadas en la composición. Uso del ángulo oblicuo, con respecto al ángulo horizontal, implica cierto distanciamiento (actitud objetiva) mientras que el ángulo frontal crea un grado alto de implicación (actitud subjetiva). En lo relativo a la distancia social ésta se establece entre creador y receptor de la imagen. Es Intima/personal (cuando se usan primeros planos); social (cuando se usan planos medios) o impersonal (si se utilizan tomas a distancia). La distancia social también implica el grado de poder entre el emisor y receptor. En este sentido, el uso del ángulo vertical define dos tipos de relaciones posibles: la de los participantes dentro de la imagen y la de éstos y el espectador. Dependiendo de si la toma se realiza desde un ángulo superior, medio o inferior, la relación de poder entre el receptor y el productor de la imagen será de superioridad, de igualdad o de inferioridad respectivamente (Kress y van Leeuwen, 1996).

\subsubsection{El análisis intersemiótico de Nicolajeva y Scott (2001)}

Una vez realizado el análisis semiótico-social desde la óptica de Kress y van Leewen (1996) nos enfocamos en revisar la interacción que se produce entre el texto y la imagen en el corpus de trabajo, aplicando el Modelo de Nikolajeva y Scott (2001). El modelo en cuestión viene a suplir un vacío en este tipo de análisis intersemiótico, puesto que si bien Kress y van Leeuwen creen que el componente visual y verbal entablan una estrecha relación, consideran que no existe dependencia directa entre ambos sistemas semióticos, razón por la cual no focalizan su interés en este tipo de correlaciones.

En función de la complementariedad que existiría entre texto/imagen Nikolajeva y Scott (2001) proponen 5 categorías de análisis para describir la interrelación entre los elementos visuales y verbales en cuentos infantiles. Creemos propicia la aplicación de este constructo en la medida que consideramos la noticia como una narración o relato, tal y cual lo hemos afirmado anteriormente. Estas categorías analíticas de interacción texto/imagen que proponen los autores mencionados las aplicaremos en el corpus de trabajo para determinar la forma en que se produce intersemiosis para crear significados sobre lo étnico.

La primera interacción es la de simetría que es aquella que se produce cuando las imágenes y las palabras cuentan la misma historia básicamente repitiendo información 
mediante movimientos comunicativos diferentes. El segundo tipo es la ampliación que se da cuando las imágenes amplían el significado de las palabras o, viceversa, cuando las palabras amplían a las imágenes de forma que la información de ambos modos de comunicación genera una dinámica más completa. La tercera interacción es muy significativa y la dinámica se convierte en realmente complementaria. En tanto, la dinámica de contrapunto puede darse cuando las palabras y las imágenes colaboran para comunicar significados que superan el alcance de cada uno elemento por sí mismo. En último lugar, Nikolajeva y Scott (2001) hablan de interacción contradictoria cuando las palabras y las imágenes parecen oponerse mutuamente.

Hasta aquí hemos desarrollado los constructos teórico-metodológicos que nos parecen adecuados para su aplicación a un corpus multimodal. Esto nos facilitará el determinar las categorías de análisis y diseñar los instrumentos de recogida de datos para su posterior procesamiento e interpretación semiótica. Las matrices de análisis que han resultado de la extracción de categorías semióticas y discursivas desde los respectivos cuerpos teóricos revisados se operacionalizan en el siguiente apartado.

\section{DEFINICIÓN Y DISEÑO DE LAS CATEGORÍAS DE ANÁLISIS. ELABORACIÓN DE LAS MATRICES PARA EL ANÁLSIS HOLÍSTICO MULTIMODAL}

Como ya hemos advertido, a partir de los elementos y teorías descritos en el apartado anterior, nos abocamos a elaborar los instrumentos o matrices de análisis que nos permite aplicarlos a la muestra seleccionada para nuestro objeto de estudio, lo cual nos permite alcanzar las metas propuestas en este trabajo.

El procedimiento metodológico a seguir consiste en elaborar instrumentos analíticos formados por categorías semio-discursivas que pertenecen a un conjunto teórico interdisciplinario muy acorde a los objetivos que nos hemos fijado. Los mencionados instrumentos están conformados de diferentes columnas donde podemos vaciar, tanto la unidad de análisis (textos visuales y verbales), como las categorías teórico-analíticas que nos sirven en este modelo holístico multimodal.

Para este trabajo hemos utilizado 4 matrices de análisis, a saber: para el contenido semiodiscursivo del texto periodístico trabajamos con un instrumento aportado por Velázquez (2011) y que se encuentra en Anexo; dos matrices que nos sirve para analizar las fotografías de las noticias y las relaciones intersemióticas, respectivamente - las que se operativizan en el apartado 5.2 y que son de creación propia del autor de este estudio - y la matriz resultante del modelo sociocognitivo de van Dijk (1990, 1997a, 2003a, 2003b). Esta última se ha diseñado especialmente para esta investigación y que, por razones de espacio, presentamos en Anexo. 


\section{APLICACIÓN DEL MODELO HOLÍSTICO MULTIMODAL AL CONFLICTO MAPUCHE EN CHILE}

\subsection{Validación de los instrumentos}

Las cuatro matrices de análisis propuestas se han validado en diversos trabajos en que el autor ha expuesto su aplicación al problema étnico mapuche. Es así como se puede apreciar en Sáez (2015, 2016, 2019 a, 2019b) variados ejemplos de cómo operan las matrices y sus categorías analíticas para un corpus extraído de la prensa chilena relativo a la construcción periodística de la minoría étnica mapuche.

\subsection{Análisis y resultados}

El corpus del estudio está conformado por 66 noticias referidas a la huelga de hambre que, en los años 2010 y 2020, se sometieron un grupo de prisioneros encarcelados en el marco del denominado conflicto mapuche. Desde el Diario El Mercurio se extrae el 52\% del total de la muestra, mientras que del Diario La Cuarta, el 48\% del total del corpus. Dado el escaso espacio, mostramos el análisis de algunos casos ilustrativos de la muestra para comprobar cómo opera el Modelo planteado.

\subsubsection{Mostrar (in)visibilizando: el racismo visual en las fotografias periodísticas}

Como es posible apreciar en las 4 fotografías periodísticas que se encuentran al final de este párrafo - y que se presentan como casos representativos de la muestra - podemos sostener que las elecciones visuales confirman nuestra idea que a través de ellas se produce y reproduce una visión discriminatoria y racista del exogrupo y una visión positiva del endogrupo para construir visualmente la protesta indígena. Dichas selecciones de imágenes - las que no resultan azarosas ni antojadizas y no necesariamente conscientes - reflejarían la adopción de una representación ideológica que semiotiza diferenciada y dicotómicamente a la elite dominante y al grupo subalterno. En efecto, de la operación contrastiva de las imágenes, se puede concluir que a la elite gobernante se le construye visualmente recurriendo a la centralidad focal de las tomas usadas, al uso de primeros planos, a la ubicación hacia el centro de las imágenes que los retratan y el gran tamaño de éstas, como asimismo la utilización de mayor contraste y saturación de colores en la representación. Lo anterior, visibiliza al Gobierno como entidad poderosa y con gran status social Por otro lado, a los representantes de la etnia mapuche se les construye visualmente mediante tomas fotográficas en las que prevalece el ángulo superior indicativo de relaciones de superioridad y el ángulo oblicuo para significar distanciamiento con la cultura mapuche por parte de la sociedad mayoritaria, y por otro, la ubicación polarizada de la noticia, lo que refleja escasa importancia y valorización social por parte de la prensa del mundo aborigen. 
Elecciones visuales de Los Otros

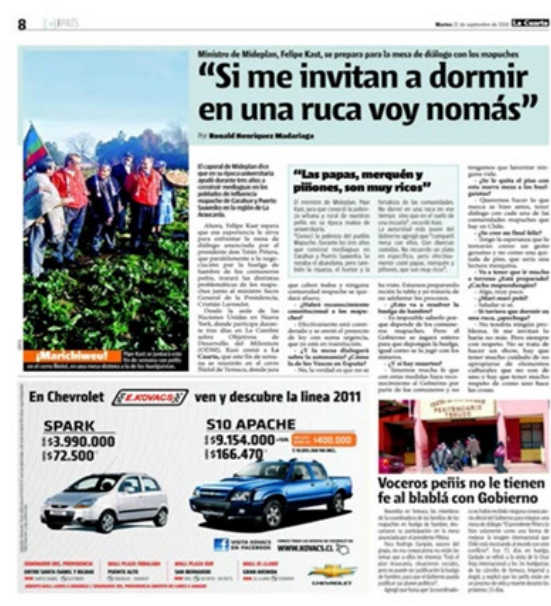

Texto 1

Diario La Cuarta (19/09/2010)

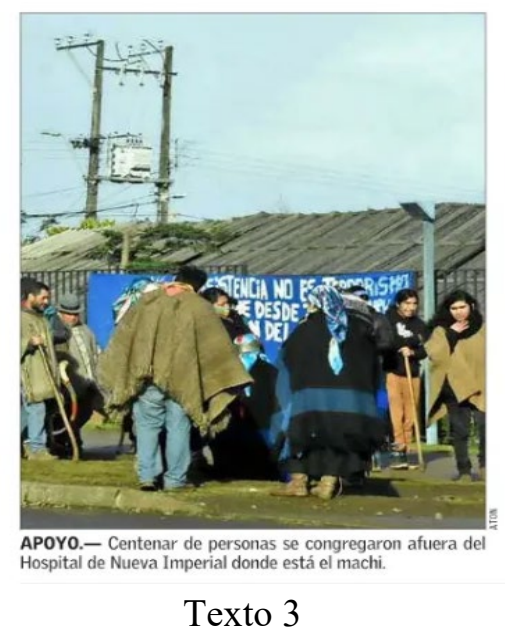

Diario El Mercurio (16/08/2020)
Elecciones visuales del Nosotros

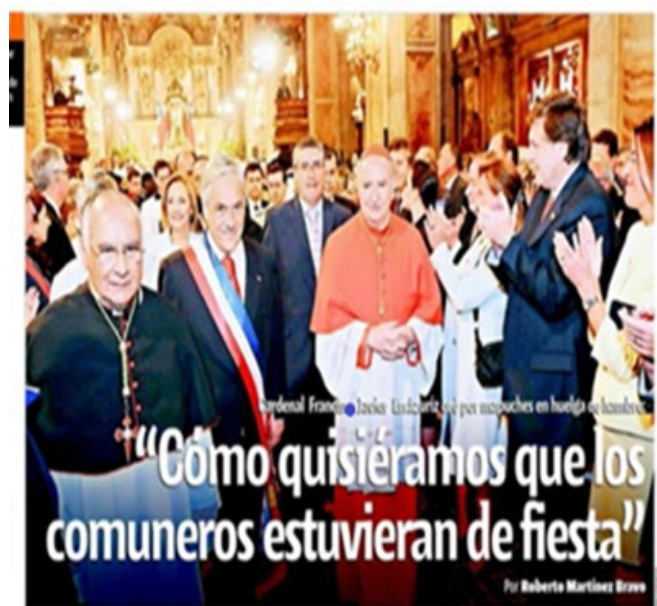

Texto 2

Diario El Mercurio (18/09/2010)

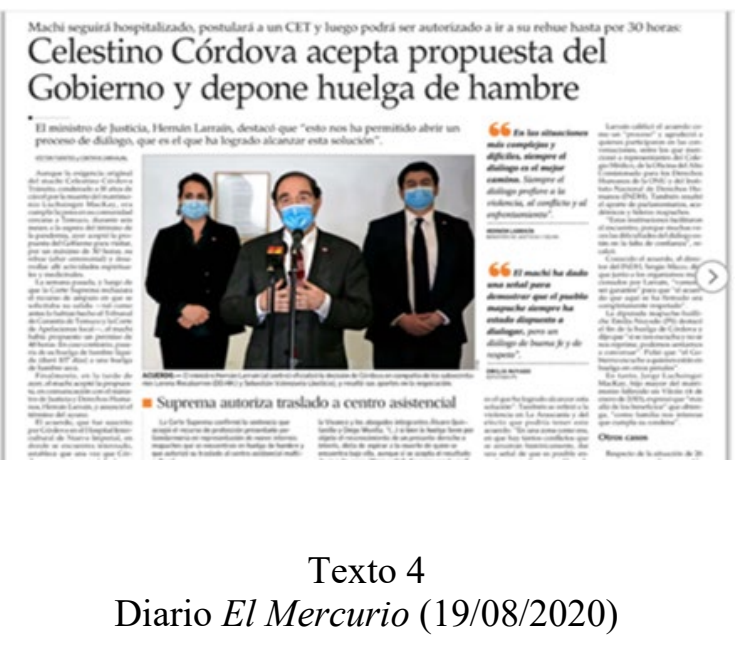

En efecto, se produce una lucha simbólica en la que dos mundos —el del Nosotros, los blancos y el de los Otros, los mapuches - han sido semiotizados por la prensa estudiada como superior e inferior, respectivamente. Consecuentemente, se produce una invisibilización de la etnia mapuche y sus demandas sociales, culturales y políticas.

A continuación, en la Tabla 1 - con el propósito de dar sustento a la discusión de los resultados - se provee la operativización de la matriz semiótico-visual de Kress y van Leeuwen (1996) con la que se analiza las 4 fotografías ya comentadas. 


\begin{tabular}{|c|c|c|c|c|c|}
\hline \multicolumn{6}{|c|}{ Significados sociales } \\
\hline Funciones & & $\begin{array}{l}\text { Texto 1 } \\
\text { La Cuarta } \\
\text { 19/09/2010 }\end{array}$ & $\begin{array}{l}\text { Texto } 2 \\
\text { La Cuarta } \\
21 / 09 / 2010\end{array}$ & $\begin{array}{l}\text { Texto } 3 \\
\text { El Mercurio } \\
18 / 08 / 2020\end{array}$ & $\begin{array}{l}\text { Texto } 4 \\
\text { El Mercurio } \\
19 / 08 / 2020 \\
\end{array}$ \\
\hline $\begin{array}{l}\text { Función } \\
\text { Ideacional }\end{array}$ & & $\begin{array}{l}\text { Imagen } \\
\text { conceptual } \\
\text { simbólica: } \\
\text { "estos son los } \\
\text { voceros } \\
\text { mapuches". }\end{array}$ & $\begin{array}{l}\text { Imagen } \\
\text { narrativa: El } \\
\text { Presidente } \\
\text { Sebastián } \\
\text { Piñera sale del } \\
\text { Te Deum } \\
\text { celebratorio de } \\
\text { la } \\
\text { Independencia } \\
\text { de Chile. }\end{array}$ & $\begin{array}{l}\text { Imagen } \\
\text { Narrativa: } \\
\text { Los vectores } \\
\text { de } \\
\text { movimiento y } \\
\text { miradas nos } \\
\text { narran una } \\
\text { marcha de } \\
\text { apoyo a los } \\
\text { huelguistas } \\
\text { mapuches. }\end{array}$ & $\begin{array}{l}\text { Imagen } \\
\text { conceptual } \\
\text { simbólica: } \\
\text { "Representantes } \\
\text { del Gobierno: el } \\
\text { Ministro de } \\
\text { Justicia y los } \\
\text { Subsecretarios } \\
\text { de Estado" }\end{array}$ \\
\hline \multirow[t]{4}{*}{$\begin{array}{l}\text { Función } \\
\text { Interpersonal }\end{array}$} & $\begin{array}{l}\text { Contacto } \\
\text { visual }\end{array}$ & $\begin{array}{l}\text { Sin contacto: } \\
\text { Oferta. Son } \\
\text { sujetos pasivos } \\
\text { en relación } \\
\text { con lector. }\end{array}$ & $\begin{array}{l}\text { Imagen de } \\
\text { Demanda: el } \\
\text { Presidente } \\
\text { demanda } \\
\text { atención } \\
\text { mirando al } \\
\text { receptor. } \\
\text { Cobra } \\
\text { agentividad. }\end{array}$ & $\begin{array}{l}\text { No hay } \\
\text { contacto } \\
\text { visual. Se } \\
\text { decodifica } \\
\text { como Oferta: } \\
\text { Sujetos } \\
\text { pasivos a la } \\
\text { mirada del } \\
\text { lector. }\end{array}$ & $\begin{array}{l}\text { Imagen de } \\
\text { Demanda: Las } \\
\text { autoridades de } \\
\text { Justicia miran } \\
\text { al lector. } \\
\text { Cobran } \\
\text { agentividad } \\
\text { frente a la } \\
\text { pasividad del } \\
\text { Receptor. }\end{array}$ \\
\hline & $\begin{array}{l}\text { Distancia } \\
\text { social }\end{array}$ & $\begin{array}{l}\text { Media: } \\
\text { objetividad en } \\
\text { la relación } \\
\text { entre creador } \\
\text { imagen y } \\
\text { receptor. }\end{array}$ & $\begin{array}{l}\text { Toma en } \\
\text { primer plano: } \\
\text { relación de } \\
\text { intimidad } \\
\text { entre } \\
\text { participantes y } \\
\text { receptor }\end{array}$ & $\begin{array}{l}\text { Media: } \\
\text { objetividad } \\
\text { en la relación } \\
\text { entre emisor } \\
\text { y receptor }\end{array}$ & $\begin{array}{l}\text { Toma en Primer } \\
\text { plano: relación } \\
\text { de intimidad } \\
\text { entre Emisor y } \\
\text { Receptor y } \\
\text { entre } \\
\text { Participantes y } \\
\text { espectador }\end{array}$ \\
\hline & $\begin{array}{l}\text { Grado } \\
\text { implicación y } \\
\text { actitud }\end{array}$ & $\begin{array}{l}\text { Angulo } \\
\text { oblicuo de } \\
\text { toma: } \\
\text { desimplicación } \\
\text { del emisor y } \\
\text { receptor de la } \\
\text { imagen con el } \\
\text { mundo } \\
\text { mapuche }\end{array}$ & $\begin{array}{l}\text { Angulo frontal } \\
\text { de la toma: } \\
\text { comunica alto } \\
\text { grado de } \\
\text { implicación } \\
\text { entre emisor y } \\
\text { receptor }\end{array}$ & $\begin{array}{l}\text { Eje vertical } \\
\text { de la imagen: } \\
\text { Angulo } \\
\text { superior de la } \\
\text { toma. La } \\
\text { relación entre } \\
\text { Receptor y } \\
\text { mapuches es } \\
\text { de asimetría. }\end{array}$ & $\begin{array}{l}\text { Eje vertical de } \\
\text { la imagen: toma } \\
\text { en ángulo } \\
\text { medio. Igualdad } \\
\text { entre los } \\
\text { participantes. }\end{array}$ \\
\hline & $\begin{array}{l}\text { Grado de } \\
\text { Poder }\end{array}$ & $\begin{array}{l}\text { Angulo } \\
\text { superior de } \\
\text { toma: relación } \\
\text { entre receptor } \\
\text { y mapuches es } \\
\text { de } \\
\text { superioridad. }\end{array}$ & $\begin{array}{l}\text { Toma de } \\
\text { ángulo medio: } \\
\text { igualdad de } \\
\text { poder entre los } \\
\text { participantes }\end{array}$ & $\begin{array}{l}\text { Eje vertical } \\
\text { de la imagen: } \\
\text { Angulo } \\
\text { superior de la } \\
\text { toma. La } \\
\text { relación entre } \\
\text { Receptor y } \\
\text { mapuches es } \\
\text { de asimetría. }\end{array}$ & $\begin{array}{l}\text { Eje vertical de } \\
\text { la imagen: toma } \\
\text { en ángulo } \\
\text { medio. Igualdad } \\
\text { entre los } \\
\text { participantes. }\end{array}$ \\
\hline
\end{tabular}

(C) UNED. Revista Signa 31 (2022), pp. 739-767

DOI: https://10.5944/signa.vol31.2022.29441

ISSN digital: 2254-9307. ISSN papel: 1133-3634 


\begin{tabular}{|c|c|c|c|c|}
\hline $\begin{array}{l}\text { Función } \\
\text { Textual }\end{array}$ & $\begin{array}{l}\text { Imagen en } \\
\text { Margen ideal } \\
\text { nuevo. } \\
\text { Pequeño } \\
\text { tamaño. Poca } \\
\text { nitidez focal y } \\
\text { escaso } \\
\text { contraste } \\
\text { tonal. Sugiere } \\
\text { escaso valor } \\
\text { social de la } \\
\text { cultura } \\
\text { mapuche. }\end{array}$ & $\begin{array}{l}\text { Imagen en } \\
\text { parte central, } \\
\text { en margen } \\
\text { superior, hacia } \\
\text { el margen } \\
\text { ideal nuevo. } \\
\text { Gran tamaño } \\
\text { de foto. Marca } \\
\text { de gran poder } \\
\text { y status. }\end{array}$ & $\begin{array}{l}\text { Imagen en } \\
\text { Centro: entre } \\
\text { ideal dado/ } \\
\text { Real dado. } \\
\text { Mediano } \\
\text { tamaño. Alta } \\
\text { nitidez focal } \\
\text { y contraste } \\
\text { tonal. Sugiere } \\
\text { alta } \\
\text { relevancia de } \\
\text { la noticia. }\end{array}$ & $\begin{array}{l}\text { Imagen } \\
\text { centralizadan } \\
\text { en parte } \\
\text { superior de } \\
\text { página. Margen } \\
\text { ideal lo } \\
\text { dado/Lo nuevo. } \\
\text { Tamaño medio. } \\
\text { Nitidez focal y } \\
\text { gran saturación } \\
\text { colores. Alto } \\
\text { poder. }\end{array}$ \\
\hline
\end{tabular}

Tabla 1

Fuente: creación del autor.

5.2.2. Los instrumentos discursivos de la prensa escrita y la protesta indígena: una mirada semántico-cognitiva

Al someter el corpus al análisis sobresalen las estrategias discursivas típicas de todo discurso ideológico (racista, en este caso): la autorrepresentación positiva del Nosotros y la representación negativa de los Otros, mediante el uso de las estrategias de legitimación propia, la de deslegitimación del oponente, respectivamente, y la interpretación implícita/explícita que realiza la prensa, dentro del hacer creer como dimensión cognitiva para la identificación negativa de la cultura mapuche. Tal como apreciamos en los ejemplos siguientes, a través su articulación en actos de habla:

5.2.2.1. La estrategia discursiva de deslegitimación del oponente. El macroacto de habla de acusación

1. Tratativas del Ministro Larraín con el Machi preso en Temuco no han prosperado, pese a que hubo apertura a que este asistiera a su Rehue por unas horas. Córdoba anuncia inicio de huelga seca, pese a gestiones y propuesta del Gobierno (El Mercurio 18/08/2020).

2. Rodrigo Hinzpetter ante huelga de hambre: "Sumar menores a la huelga es una insensatez". Los dos menores de 16 y 17 años que evalúan sumarse a la huelga que mantienen 32 comuneros mapuches por 53 días, sacó ronchas en el Gobierno. (La Cuarta, 02/09/2010).

5.2.2.2. La estrategia de legitimación propia. El macroacto de habla de autoafirmación

3. "Vamos a hacer todo lo posible para que termine la huelga. Si no termina la huelga, vamos a hacer todo lo posible por salvar vidas, para que nadie muera por el efecto de una huelga de hambre" (Víctor Pérez, Ministro del Interior. El Mercurio, 18/08/2020). 
4. "Como Presidente, no voy a permitir que ningún chileno se muera de hambre. Y mucho menos cuando lo hace por su propia voluntad" (Sebastián Piñera. Presidente de la República. La Cuarta, 19/09/2010).

5.2.2.3. El hacer creer como dimensión cognitiva: La interpretación explícita/implícita de la prensa chilena vinculada a juicios condenatorios sobre lo mapuche

La manipulación ${ }^{2}$ ejercida desde la prensa se inscribe en la esfera de lo cognitivo mediante su hacer creer y hacer saber que la evaluación que ella hace es la verdad, por medio del uso de la estrategia de la interpretación subjetiva - explícita o implícitasobre la huelga de hambre mapuche. Por ello, analizaremos a nivel de sumario de la noticia -Antetítulo (AT), Titular (T), Subtítulo (ST) y lead (L) — y sus respectivas macroestructuras cómo aquella toma una particular posición mediante el estudio de la interpretación como categoría analítica superestructural. Veamos los siguientes ejemplos del corpus:

5. (ST) "Asesina" y "traidora" son algunos de los insultos que familiares y simpatizantes de los 34 huelguistas, que ayer cumplieron 64 días sin comer, le gritaron a la ex vocera del gobierno de Bachelet. (La Cuarta, 12/09/2010). Macroestructura: Agresión verbal hacia ex vocera de Gobierno por familiares de huelguistas.

6. (T) Peñis de Angol siguen en huelga "hasta las últimas". (La Cuarta, 04/10/2010). Macroestructura: Porfía de los mapuches de Angol para continuar huelga.

7. (ST) La Moneda criticó la postura de los huelguistas y afirmó que con la petición pretendían estar "sobre el imperio de la ley". (El Mercurio, 28/09/2010). Macroestructura: La Moneda critica a los mapuches por estar fuera de la ley por solicitud de intervención del Poder Judicial.

8. Desde EE.UU. Presidente Piñera lamentó "actitud intransigente" de los mapuches en huelga. (El Mercurio, 26/09/2010). Macroestructura: Presidente critica a los mapuches por ser instransigentes al no deponer la huelga de hambre.

Del análisis de las estrategias discursivas empleadas por los diarios La Cuarta y El Mercurio se desprende que todas ellas transmiten una imagen claramente negativa del mapuche y su cultura. Las estrategias analizadas dan cuenta de una representación social negativa del mapuche, invisibilizan sus aspectos positivos y, de paso, construyen una imagen positiva del Gobierno. El discurso de la prensa ha dado forma entonces, al cuadrado ideológico, tan propio de los discursos ideológicos - en este caso de corte racista - en el que se re-produce una semiosis fronteriza entre los Otros y Nosotros. Este discurso racista detenta el poder de determinar las características identitarias del endogrupo y de perfilar los rasgos del mapuche otrificado, mediante un ataque discursivo

\footnotetext{
${ }^{2}$ Para mayor comprensión conceptual sobre la Teoría de la Manipulación, véase Greimas y Courtés (1982).
} 
que crea identidad por oposición e inscribe una relación entre los Otros y Nosotros en un plano de superioridad y dominación.

La producción noticiosa en torno a la alteridad mapuche instala un programa narrativo-manipulativo desde la modalidad factitiva, en el ámbito cognitivo, para hacer creer que la interpretación de la realidad que efectúan los diarios analizados es verdadera y se ajusta a los criterios periodísticos de objetividad. Es así como, mediante encuadres interpretativos prejuiciosos, se transmite una visión sesgada y racista de la cultura-vida mapuche a las macroestructuras de la noticia del conflicto mapuche, las que reproducen y reflejan una interpretación subjetiva - implícita o explícita - donde los medios escritos chilenos adoptan una postura de condena y rechazo a la protesta de los aborígenes. Esta postura ideológico-racista es instalada en los esquemas mentales de los lectores como verdad por medio de la fuerza ilocucionaria provista — en general — por la estrategia discursiva de la intertextualidad para producir la noticia que da tribuna en titulares, bajadas y lead a la voz de autoridades del gobierno y se omite la voz de los mapuches.

\subsubsection{La intersemiosis texto/imagen en las noticias de la huelga de hambre mapuche}

Del análisis de la intersemiosis que se produce entre las imágenes y el texto escrito, en las noticias referidas al corpus, se concluye que existe predominancia de relaciones de interacción simétrica, vale decir, que las palabras y las imágenes relatan la misma historia. Lo anterior, tiene mucha relevancia para nuestro trabajo en el sentido que observamos que los recursos visuales y verbales colaboran mancomunadamente para producir una semiosis social discriminatoria en relación al tema étnico.

En efecto, al revisar la Tabla 2 - la que contiene un ejemplo representativo de cada relación texto/imagen, según el Modelo de Nikolajeva y Scott (2001) ${ }^{3}$ - apreciamos cómo el texto lingüístico y la imagen se refuerzan sinérgicamente para construir periodísticamente al Presidente y a la élite como entes poderosos. En cambio, a los mapuches se les representa como terroristas y violentos al enfrentarse a las fuerzas de orden y seguridad. Esto muestra palmariamente la centralidad que adquieren éstos cuando de representar las acciones negativas del Otro se trata. Lo anterior, se puede confirmar en las siguientes imágenes que han servido como casos representativos de la muestra:

\footnotetext{
${ }^{3}$ En Sáez (2019a) proveemos un análisis pormenorizado de la relación texto/imagen sobre la huelga.
} 


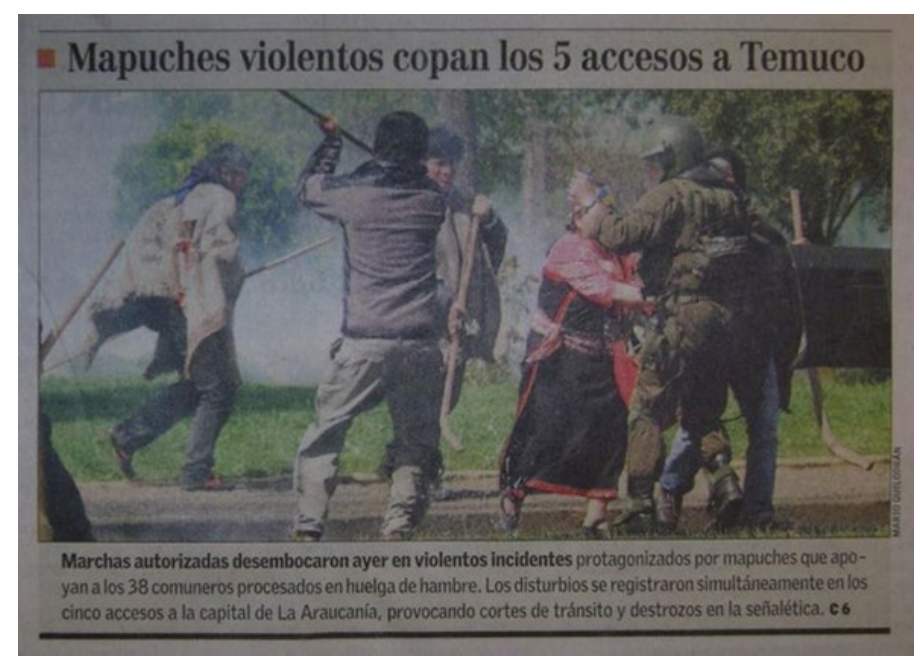

Texto 5

El Mercurio (30/09/2010)

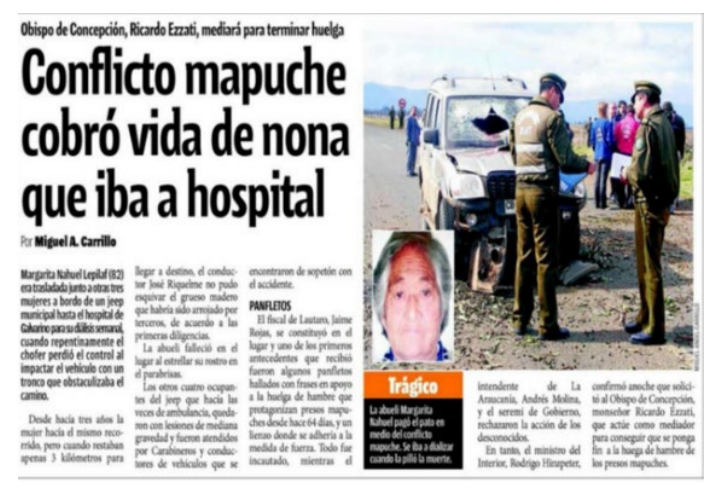

Texto 6

La Cuarta $(14 / 09 / 2010)$

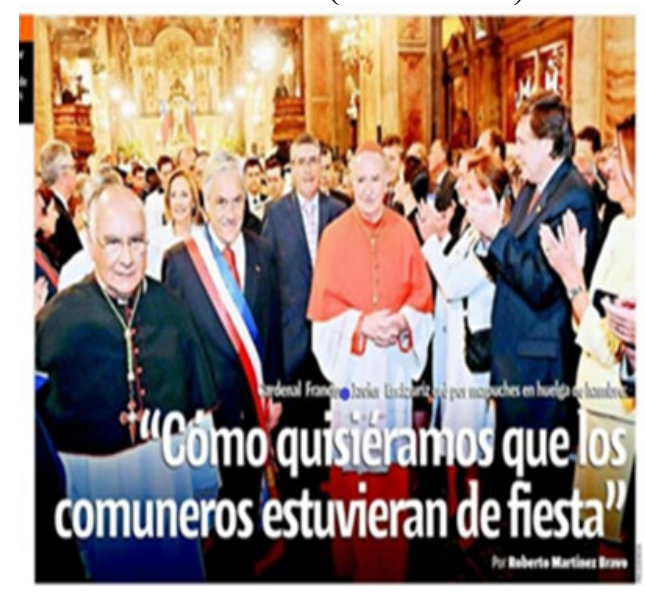

Texto 8

La Cuarta $(19 / 09 / 2010)$

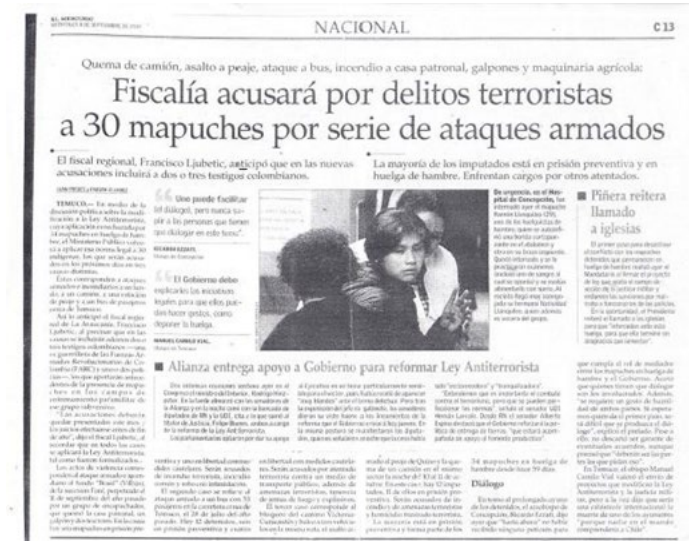

Texto 7

El Mercurio (08/09/2010)

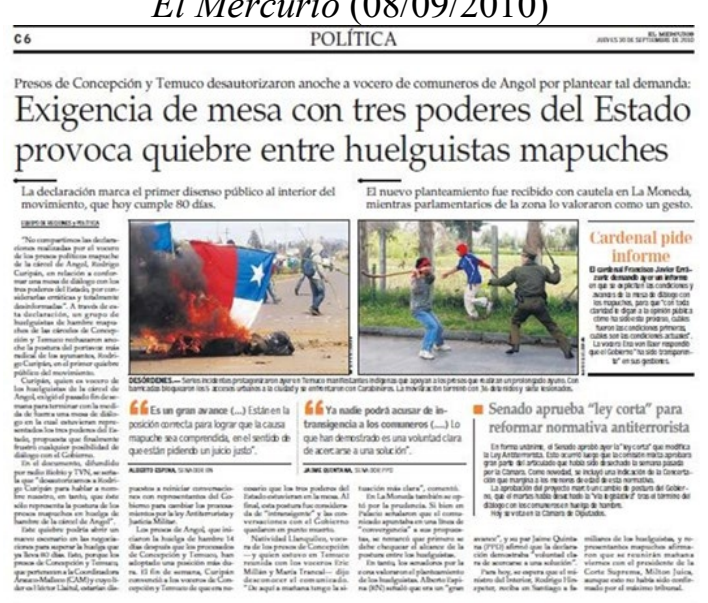

Texto 9

El Mercurio (30/09/2010) 
En este punto proveemos, a modo de ejemplo y de sustento de las conclusiones señaladas más arriba, el instrumento basado en el modelo de Nicolajeva y Scott (2001) aplicado a la muestra para el análisis de las relaciones intersemióticas.

\begin{tabular}{|c|c|c|c|c|}
\hline \multicolumn{5}{|c|}{ Relación intersemiótica - Texto/Imagen } \\
\hline Simétricas & De ampliación & Complementarias & Contradictorias & Contrapunto \\
\hline $\begin{array}{c}\text { Texto } 5 \\
\text { El Mercurio } \\
30 / 09 / 2010 \\
\end{array}$ & $\begin{array}{c}\text { Texto } 6 \\
\text { La Cuarta } \\
14 / 09 / 2010\end{array}$ & $\begin{array}{c}\text { Texto } 7 \\
\text { El Mercurio } \\
08 / 09 / 2010\end{array}$ & $\begin{array}{c}\text { Texto 8 } \\
\text { La Cuarta } \\
19 / 09 / 2010 \\
\end{array}$ & $\begin{array}{c}\text { Texto } 9 \\
\text { El Mercurio } \\
30 / 09 / 2010\end{array}$ \\
\hline $\begin{array}{l}\text { En esta } \\
\text { noticia el } \\
\text { texto escrito } \\
\text { no añade más } \\
\text { información } \\
\text { que el texto } \\
\text { visual, vale } \\
\text { decir, narran } \\
\text { los mismo: } \\
\text { mapuches } \\
\text { violentos } \\
\text { cortan los } \\
\text { accesos a } \\
\text { Temuco y se } \\
\text { enfrentan } \\
\text { violentamente } \\
\text { con } \\
\text { Carabineros. }\end{array}$ & $\begin{array}{l}\text { La fotografía } \\
\text { amplía el texto } \\
\text { escrito para dar } \\
\text { más } \\
\text { dramatismo a } \\
\text { la muerte de } \\
\text { anciana: } \\
\text { vidrios y } \\
\text { parabrisas } \\
\text { rotos; policías } \\
\text { para esclarecer } \\
\text { el accidente. }\end{array}$ & $\begin{array}{l}\text { La interacción de } \\
\text { ampliación se } \\
\text { transforma en } \\
\text { relación de } \\
\text { complementariedad: } \\
\text { el componente } \\
\text { visual ofrece una } \\
\text { información } \\
\text { relevante y } \\
\text { diferente a la dada } \\
\text { por lo verbal: se } \\
\text { retrata a Natividad } \\
\text { Llanquilieo, vocera } \\
\text { mapuche, quien } \\
\text { ingresa al hospital a } \\
\text { visitar a su hermano } \\
\text { huelguista, quien } \\
\text { está grave. Se le ve } \\
\text { angustiada. Imagen } \\
\text { alejada del } \\
\text { estereotipo de } \\
\text { "terrorista". }\end{array}$ & $\begin{array}{l}\text { Aquí las palabras y } \\
\text { las imágenes } \\
\text { parecen oponerse: } \\
\text { "Como me gustaría } \\
\text { que los comuneros } \\
\text { estuvieran de } \\
\text { fiesta” (Cardenal). } \\
\text { Mientras que una } \\
\text { de las imágenes en } \\
\text { la página se observa } \\
\text { la detención de un } \\
\text { comunero por parte } \\
\text { de la policía. }\end{array}$ & $\begin{array}{l}\text { Aquí las imágenes y } \\
\text { palabras cuentan } \\
\text { historias } \\
\text { independientes unas } \\
\text { de las otras. Las } \\
\text { imágenes muestran } \\
\text { graves disturbios. En } \\
\text { cambio, las palabras } \\
\text { hablan de un quiebre } \\
\text { en el movimiento } \\
\text { mapuche }\end{array}$ \\
\hline
\end{tabular}

Tabla 2

Fuente: Creación del autor

\section{CONCLUSIONES}

Ante la arremetida de la ideología del racismo —en sociedades globalizadas tensionadas por múltiples crisis - que se caracteriza por ser sutil, menos flagrante, edulcorada bajo un lenguaje políticamente correcto y que construye una cognición social que normaliza la exclusión de un Otro étnico, es que se hace imperativo abrir nuevos enfoques para analizar fenómenos sociopolíticos cada vez más complejos, como lo es el racismo discursivo que re-producen los medios de comunicación.

Para poder comprender, explicar e interpretar fenómenos sociales tan complejos se requiere una apertura en la mirada, que observe desde un prisma más integral y abarcador múltiples perspectivas y categorías analíticas provenientes de diversas disciplinas como la semiótica, la lingüística y los estudios del discurso periodístico. Nos parece que el ACD y su apertura hacia una semiótica social, vinculada al Análisis Crítico del Discurso 
Multimodal (ACDM) arrojan luces, en esta propuesta, no solo de las estructuras superficiales del discurso, sino de aquellas estructuras profundas que dan cuenta de una ideología racista soterrada en las estrategias discursivas de la prensa escrita estudiada y que profundiza y refuerza la discriminación y el racismo en contra de las minorías étnicas.

Por ello, nos atrevemos a afirmar que la propuesta teórico-metodológica que se aporta para los estudios del racismo discursivo - en clave crítica - es lo suficientemente adecuada para el abordaje de los mensajes periodísticos que se construyen combinando textos icónicos y verbales que requieren de un instrumental analítico capaz de abordar de forma integral e interdisciplinaria la re-producción de una semiosis mediática que perpetua la desigualdad social y el abuso de poder al construir estereotipos sociales, realidades que crean y refuerzan modelos mentales (van Dijk, 2008).

A través del Modelo aquí propuesto se aprecia cómo los diarios chilenos de mayor lectura contribuyen activamente a la re-creación y consolidación mediática de la frontera simbólico-racial entre la elite blanca chilena y las minorías étnicas que quedan marginadas, fuera de los límites de la nación. Este orden social, responde a una compleja estructuración sociohistórica que proviene de los albores de la colonización y que pervive con nuevos matices hasta nuestros días. Estructura sociosemiótica que semiotiza como superior a los grupos blancos y como subalternos a los grupos étnicos minoritarios. Los medios de comunicación escritos, como los diarios El Mercurio y La Cuarta, colaboran como parte de la élite dominante a conservar este orden social desigual que genera racismo y que luego se trasunta en sus rutinas de fabricación de la noticia relativas a los temas étnicos. En efecto, tal como van Leeuwen (2000: 333) habló de "racismo visual", plantemos el uso de una violencia étnica visual, congruente con la idea de que las razas son primigeniamente una realidad visual. En los medios de comunicación se ejerce una violencia visual hacia los grupos étnicos minoritarios, al ser representados como personas subalternas, siempre en actitudes donde no tienen agentividad, vinculadas a problemas sociales como violencia, marginalidad, terrorismo, etc.

El modelo propuesto deja en evidencia que el texto verbal e icónico trabajan conjuntamente para crear y legitimar una determinada semiosis social: el poder y prestigio social del gobierno y las clases dirigentes en contraposición de la desvaloración cultural y política del mundo mapuche y consecuencialmente, la invisibilización y criminalización de sus históricas reivindicaciones. En tanto construcción periodística, las imágenes que acompañan a las noticias adquieren un carácter interpretativo (Navas, 1995) en la medida que éstas guían la interpretación del texto en su totalidad y generan un camino hermenéutico unívoco en el plano semántico-cognitivo que induce al lector a considerar como cierta y posible la realidad representada. 


\section{REFERENCIAS BIBLIOGRÁFICAS}

AlONSO, I. ET AL. (2010). "In their own Words: the Construction of the Image of Immigrant in Peninsular Spanish Broadsheets and Freesheets". Discourse and Communication 4.3, 227-242.

Arrunategui, C. (2010). "El racismo en la prensa escrita peruana". Discurso \& Sociedad 4.3, 428-470.

Austin, J. (1971). Palabras y acciones. Cómo hacer cosas con palabras. Buenos Aires: Paidós.

BALDRY, A. (2004). "Phase and Transition Type and Instance: Patterns in Media Texts as Seen Through a Multimodal Concordancer". En Multimodal Discourse Analysis, K. O’Halloran (ed.), 83-108. Londres: Continuum.

BengoA, J. (1999). Historia de un conflicto. El Estado y los Mapuches en el siglo XX. Santiago: Planeta.

Checa y Olmos, F., ED. (2008). La inmigración sale a la calle. Comunicación y discursos sobre el discurso migratorio. Barcelona: Icaria.

De Barros, F. E PAgliuchi, R. (2018). "A representação do negro no regime escravocrata brasileiro em texto multimodal". Contracorriente 11, 29-38.

DiJK, T. VAN (1983). "Estructuras textuales de la noticia de prensa". Análisi. Quaderns de comunicació i cultura 7-8, 77-105.

(1984). Prejudice in Discourse: An Analysis of Ethnic Prejudice in Cognition and Conversation. Amsterdam / Philadelphia: John Benjamins.

(1990). La noticia como discurso: comprensión, estructura y producción de la información. Barcelona: Paidós.

(1997a). "Discurso, cognición y sociedad". Signos. Teoría y práctica de la educación 22, 66-74.

(1997b). Racismo y análisis crítico de los medios. Barcelona: Paidós.

(1999). “¿Un estudio lingüístico de la ideología?”. En Discurso, cognición y educación. Ensayos en honor a Luis A. Gómez Macker, G. Parodi Sweis (ed.), 2742. Valparaíso: Universidad Católica de Valparaíso.

(2002). "El análisis crítico del discurso y el pensamiento social". Revista Atenea Digital 1, 18-24.

(2003a). Ideología y discurso. Barcelona: Ariel.

(2003b). "La multidisciplinariedad del análisis crítico del discurso: un alegato a favor de la diversidad". En Métodos de análisis crítico del discurso, R. Wodak y M. Meyer (comps.), 43-177. Barcelona: Gedisa.

(2005). "El discurso como interacción en la sociedad". En El discurso como interacción social, T. van Dijk (ed.), 19-66. Barcelona: Gedisa.

(2006). "Discurso de las élites y racismo institucional”. En Medios de comunicación e inmigración, M. Lario (ed.), 15-34. Murcia: CAM-Obra Social. 
(2008): "Reproduciendo el racismo: El rol del racismo". En Contrapuntos y entrelíneas sobre cultura, comunicación y discurso, C. Del Valle et al. (eds.). Temuco: Ediciones Universidad de La Frontera.

(2010). "Análisis del discurso del racismo". Crítica y Emancipación 2.3, 65-94.

GONZÁLEZ, M. (2002). La estructura del párrafo de entrada de la noticia o lead. Munich: Lincom Europa.

Greimas, A. y Courtés, J. (1982). Diccionario razonado de la teoría del lenguaje. Madrid: Gredos.

Habermas, J. (1987). Teoría de la acción comunicativa I. Racionalidad de la acción y racionalización social. Madrid: Taurus.

Halliday, M. y Matthiesen, C. (2004). An Introduction to Functional Grammar. London: Hodder Arnold.

IMBERT, G. (1985). "Encuentros sobre metodología del análisis de la prensa (en torno a El País)”. Mélanges de la Casa de Velázquez 21, 451-463.

JEwitT, C. \& KRESS, G. (2003). “A Multimodal Approach to Research in Education”. En Language, Literacy and Education: A Reader, S. Goodman, T. Lillis, J. Mayben $\&$ N. Mercer (eds.), 277-292. Londres: Trentham Books.

KRESS, G. \& VAN LEeUwen, T. (1996). Reading Images. London: Routledge.

LARIO, M., ED. (2006). Medios de comunicación e inmigración. Murcia: CAM-Obra Social.

LeEUwen, T. VAN (2000). "Visual racism". En The Semiotics of Racism. Approaches in Critical Discourse Analysis, M. Reisigl \& R. Wodack (eds.), 333-350. Viena: Passagen Verlag.

LORITE, N. (2010). “Televisión informativa y modelos de dinamización intercultural”. En Migraciones, discursos e ideologías en una sociedad globalizada. Claves para su mejor comprensión, M. Martínez (ed.), 19-42. Alicante: Instituto Alicantino de Cultura Juan Gil-Albert.

Markovitz, J. (2011). Racial Spectacles. Exploration in media, Race, and Justice. London / New York: Routledge.

MARTínEZ, M. (2010a). "Hacia una deconstrucción de la ideología sobre la inmigración en la prensa gratuita a través de las palabras y las imágenes”. En Migraciones, discursos e ideologías en una sociedad globalizada. Claves para su mejor comprensión, M. Martínez (ed.), 143-160. Alicante: Instituto Alicantino de Cultura Juan Gil-Albert.

(2008). "Las relaciones entre las características lingüísticas y visuales de las noticias sobre inmigración en la prensa gratuita y la relación interpersonal con la audiencia”. Discurso \& Sociedad 2.4, 799-815.

(2006). "Una aproximación a la imagen del inmigrante en los textos multimodales de la prensa alicantina. ¿Estereotipos o realidad?’. En Otras miradas sobre la inmigración, C. Gómez Gil (ed.), 151-74. Alicante: Universidad de Alicante. 
MARTÍNEZ, M. y CRESPO, E. (2010b). "Recursos léxicos y visuales en la representación periodística del inmigrante”. En Migraciones, discursos e ideologías en una sociedad globalizada. Claves para su mejor comprensión, M. Martínez (ed.), 79106. Alicante: Instituto Alicantino de Cultura Juan Gil-Albert.

Mella, E. (2007). Los mapuche ante la justicia. La criminalización de la protesta indígena en Chile. Lom: Santiago.

(2008). "Criminalización de la protesta mapuche. Antecedentes históricos y sociales". Revista Reflexión 36, 1-6.

NAVAS, G. (1995). Introducción a la Literatura Infantil: fundamentación teórico-crítica, Caracas: Universidad Pedagógica Experimental Libertador.

Nikolajeva, M. \& ScotT, C. (2001). How Picturebooks Work. New York / London: Garland Publishing.

PARDO, N. (2016). "Exploraciones sobre la pobreza y el racismo en Colombia. Estudio Multimodal". Revista Latinoamericana de Estudios del Discurso 12.1, 99-117. Disponible en línea: http://dx.doi.org/10.35956/v.12.n1.2012 [02/01/2021].

Pinheiro, V. E MagalHÃEs, C. (2011). "Representações de identidades raciais em capas da revista Raça Brasil: um estudo à luz da gramática do design visual”. Cadernos de estudos lingüísticos 53.1, 39-58. Disponible en línea: https://doi.org/10.20396/ cel.v53i1.8636543 [10/11/2020].

RodríGUEZ, D. Y VELÁZQUEZ, A. (2011). “Análisis crítico del discurso multimodal en la caricatura internacional del periódico The Washington Post". Cuadernos de Lingüistica Hispánica 17, 39-52.

ROYCE, T. (2007). "Intersemiotic Complementarity: A Framework for Multimodal Discourse Analysis". En New Directions in the Analysis of the Multimodal Discourse, T. Royce \& W. Bowcher (eds.), 63-109. New Jersey: Lawrence Erlbaum Associates.

(1998). "Synergy on the Page: Exploring Intersemiotic Complementarity in Pagebased Multimodal Text". Japan Association Systemic Functional Linguistics Occasional Papers 1.1, 25-50.

SÁEZ, J. (2019a). "La construcción periodística de la cultura mapuche en la prensa escrita de Chile". Zer 24.46, 13-36. Disponible en línea: https://doi.org/10.1387/ zer.19930 [20/12/2020].

(2019b). "Ideología, poder y manipulación: la cultura mapuche y los instrumentos discursivos de la prensa chilena”. Signa: Revista de la Asociación Española de Semiótica 28, 1357-1381. Disponible en línea: https://doi.org/10.5944/ signa.vol28.2019.25122 [20/01/2020].

(2016). "Racismo en la prensa chilena: deconstrucción de la frontera simbólica en la representación social del Mapuche como el otro". Contextos: Estudios de Humanidades y Ciencias Sociales 32, 121-134.

(2015). "Análisis crítico del discurso y representación de los mapuches en la prensa escrita chilena”. Lenguas y Literaturas Indoamericanas 17, 145-169. 
SEARLe, J. (1980). Actos de habla. Ensayo de filosofía del lenguaje. Madrid: Cátedra.

UnsworTH, L. (2006). "Towards a Metalanguage for Multiliteracies Education: Describing the Meaning-making Resources of Language-Image Interaction". English Teaching: Practice and Critique 5.1, 55-76.

VelÁzQuez, T. (1982). El discurso televisivo desde la perspectiva de la lingüística textual. Un caso concreto: la entrevista. Bellaterra: Universidad Autónoma de Barcelona.

(1992). Los políticos y la televisión. Aportaciones de la teoría del discurso al diálogo televisivo. Barcelona: Ariel.

(2011). "Las técnicas del análisis socio-semiótico". En La investigación en comunicación. Métodos y técnicas en la era digital, L. Vilches (coord.), 237-265. Barcelona: Gedisa.

VelÁzQuez, T. y FonTCUBERTA, M. DE (1986). “Análisis discursivo del seguimiento de una noticia a través de dos diarios: La Vanguardia y El País”. En Investigaciones Semióticas, I: Actas del I Simposio internacional de la Asociación Española de Semiótica celebrado en Toledo durante los días 7, 8 y 9 de junio de 1984, 543562. Madrid: CSIC-AES.

ViCENTINI, S. E CARMO, C. DO (2010). "Um estudo da representação sociossemiótica do negro na revista Raça Brasil". Estudos Semióticos 6.1, 65-77.

Wieviorka, M. (1992). El espacio del racismo. Barcelona: Paidós. 


\section{ANEXO 1}

Matriz de análisis del modelo sociocognitivo de van Dijk (1990, 1997, 2003a, 2003b)

\begin{tabular}{|c|c|c|c|c|c|}
\hline $\begin{array}{c}\text { Características } \\
\text { Verbales }\end{array}$ & & Texto Fecha & Texto Fecha & Texto Fecha & Texto Fecha \\
\hline \multirow{2}{*}{$\begin{array}{l}\text { Enfatizar lo } \\
\text { positivo del } \\
\text { Nosotros. }\end{array}$} & $\begin{array}{l}\text { Estrategia } \\
\text { intertextual. }\end{array}$ & & & & \\
\hline & $\begin{array}{l}\text { Predicación, } \\
\text { agencia y } \\
\text { selección léxica. }\end{array}$ & & & & \\
\hline \multirow{4}{*}{$\begin{array}{l}\text { Enfatizar lo } \\
\text { negativo del } \\
\text { Otro. }\end{array}$} & $\begin{array}{l}\text { Explicitación } \\
\text { Grupo étnico }\end{array}$ & & & & \\
\hline & $\begin{array}{l}\text { Hiperbolización } \\
\text { numérica. }\end{array}$ & & & & \\
\hline & $\begin{array}{l}\text { Estrategia } \\
\text { intertextual. }\end{array}$ & & & & \\
\hline & $\begin{array}{l}\text { Predicación, } \\
\text { agencia y } \\
\text { selección léxica. }\end{array}$ & & & & \\
\hline $\begin{array}{l}\text { Desenfatizar lo } \\
\text { positivo del Otro. }\end{array}$ & $\begin{array}{l}\text { Conectores de } \\
\text { contrastes. }\end{array}$ & & & & \\
\hline $\begin{array}{l}\text { Desenfatizar lo } \\
\text { negativo del } \\
\text { Nosotros. }\end{array}$ & Modalización. & & & & \\
\hline
\end{tabular}

Fuente: Creación del autor. 


\section{ANEXO 2}

Matriz de análisis semiótico-discursivo del texto periodístico, de Teresa Velázquez (2011)

\begin{tabular}{|c|c|c|c|c|c|c|c|c|c|}
\hline 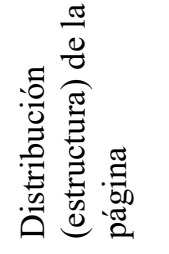 & 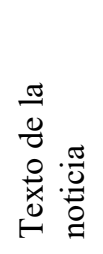 & 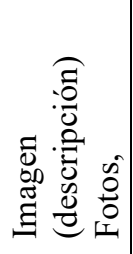 & 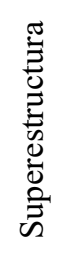 & 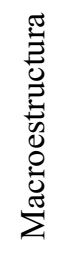 & 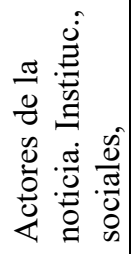 & 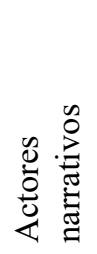 & $\begin{array}{l}\frac{7}{\pi} \\
\frac{\pi}{7} \\
\frac{\pi}{0} \\
0 \\
\Sigma\end{array}$ & 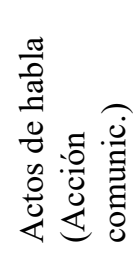 & 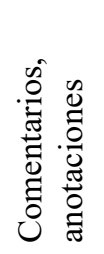 \\
\hline \multicolumn{10}{|l|}{ Antetítulo } \\
\hline \multicolumn{10}{|l|}{ Título } \\
\hline \multicolumn{10}{|l|}{$\begin{array}{l}\text { Bajada o } \\
\text { subtítulo 1 }\end{array}$} \\
\hline Lead & & & & & & & & & \\
\hline
\end{tabular}

(c) $(9)$ This work is licensed under a Creative Commons AttributionNonCommercial-NoDerivatives 4.0 International (CC BY-NC-ND).

El/la firmante del artículo se responsabiliza de las licencias de uso de las imágenes.

Fecha de recepción: 16/01/2021

Fecha de aceptación: 30/06/2021 